\title{
Truth, knowledge, and power
}

\author{
Censorship and censoring policies \\ in the Swedish public library system
}

Jon Helgason

As Nicholas J. Karolides states in Banned Books: Literature Suppressed on Political Grounds, the suppression of literature is not limited to dictatorships and authoritarian states. ${ }^{1}$ In fact, governments of democracies for various, mostly 'well-intended', reasons sometimes attempt to censor different forms of expression. Also, and for the purposes of this study more importantly, Karolides refutes the belief that censorship for political reasons only emanates from national governments. Another common source of politically motivated censorship is found at the local community level. The source of such activities is sometimes school board members or citizens, individually or in groups, who for political reasons try to censor textbooks and fiction used in schools or available in school libraries. ${ }^{2}$ Even though Karolides' description in this case primarily concerns American conditions, similar observations, as will be shown in this study, can be made in a democratic society such as Sweden. ${ }^{3}$

In recent decades there have been several (some of them highly publicized) complaints to the Parliamentary Ombudsmen, concerning what has been perceived as ideological censoring and censorship in the Swedish public libraries sector, primarily concerning publications with a perceived right-wing, nationalist, or anti-immigration agenda. The task of the Parliamentary Ombudsmen, who are independent and answer directly to Parliament, is 
to ensure that public authorities and their staff comply with the law, to review the implementation of the law in the public sector on behalf of the Swedish Parliament, and to monitor the public administration and the executive. Their remit includes the courts and other public authorities.

This investigation will study three cases where the Parliamentary Ombudsmen ruled in favour of complainants concerning 'censorship' and 'ideological activism' by Swedish public libraries. ${ }^{4}$ It shows how other public cultural policies seem to come into conflict with constitutional principles such as the freedom of opinion, especially where librarians and other public officials were accused of unlawful 'activism', examining the legal ramifications and the nature of the conflict between the various principles and policies. Together, the three cases underscore the inherent conflict in the Enlightenment heritage of modern liberal democracies, which has to do with 'the search for means both to liberate the individual and to foster social cohesion and conformity. ${ }^{5}$

\section{Democratic society and the public library system}

'A democratic society must rest on a democratic culture'. This is one of the conclusions of an official report on the state of democracy in Sweden published in $2016 .{ }^{6}$ The report elaborates on the importance of free speech and free culture, and emphasizes culture and the arts (literature, music, theatre, and other cultural expressions) as being instrumental in democracy, since such modes of expressions convey thoughts and ideas that are not normally encompassed by the formal institutions of the state. ${ }^{7}$ This sentiment is also telling for the instrumental function of the Swedish public library system. In another recent official report, the Swedish public library system is referred to as 'the fifth estate. ${ }^{8}$ As a motto, this is revealing about the self-understanding of the Swedish library sector. By extension, 'the fifth estate' refers to the classic Estates of the Realm (clergy, nobility, and commoners, and later the 'fourth estate', the press) and the traditional separation of powers in democratic societies 
(the legislature, the administration, and the judiciary). The report stresses the need for a well-functioning public library system in order for Sweden to withstand the rise of the authoritarian and right-wing populist movements witnessed in both the US and Europe. ${ }^{9}$ The library system, the report states, should act as a counterweight to the failing traditional media and to 'alternative facts'. By referring to it as 'the fifth estate', the report acknowledges the library system as 'an independent, autonomous, neutral force that provides knowledge and information to the citizens in order for them to function as citizens'. This line of reasoning underscores the perceived constitutional function of the Swedish public library system as well as the legal framework the Swedish public library system rests on.

\section{The Library Act}

The first Library Act (SFS 1996:1596), which set out the basic regulation of public libraries, came into effect on 1 January 1997. Before that, no legislation had dealt specifically with public libraries, apart from generic regulations concerning government expenditure. As of 2014, a new, revised Library Act (SFS 2013:801) is in effect. However, there are no detailed provisions in either Act about how local authorities should organize and manage library services. This adheres to a long-established principle in Swedish cultural policy, which dictates that the state should support, not govern, the cultural sector. ${ }^{10}$

There is reason to consider some aspects of the Swedish Library Act. Article 2 stipulates that the public library system should promote literature and the interest in knowledge, information, education, and research, as well as other cultural activities in general. ${ }^{11}$ This Article also spells out that the purpose of a public library system is to promote a democratic, constitutional state by the mediation of knowledge and freedom of opinion. The legislative history of the Act also states that libraries are to 'contribute to a desirable societal development in general. ${ }^{12} \mathrm{~A}$ fundamental tenet of Article 2 is that well-informed 
citizens with freedom of opinion as well as freedom of expression will further democracy. This requires that the library system itself should have a neutral position as to which information citizens can accesss. Article 6 sets down that all local authorities are required by law to uphold public libraries, and that the supply and range of books and other media products should be based on 'comprehensiveness and quality'. The legislative history of the Act explains that the libraries' supply and range are of particular importance since accessibility of information is a necessary prerequisite for public discourse and every citizen's fundamental right to freedom of information. ${ }^{13}$ Article 9 regulates that public libraries are to allow the public to borrow printed works, regardless of format, for a certain length of time or otherwise make them available free of charge. Articles 14 and 15 stipulate that regional libraries, book depositories, university libraries, research libraries, and other libraries financed by the state are required to make printed works from their collections available to public libraries free of charge. These institutions are furthermore required to cooperate with public libraries and school libraries, and assist them in their provision of good library services.

The former Chancellor of Justice and one of Sweden's foremost experts on freedom of speech and freedom of the press, Johan Hirschfeldt, has on several occasions commented upon the legal underpinnings of the Swedish library system. He stresses the democratic and constitutional context of the Swedish Library Act. ${ }^{14}$ The key words in the Act-freedom of opinion, neutrality, comprehensiveness, public accessibility - are closely linked to the Swedish Constitution, meaning the Instrument of Government (Regeringsformen, $R F$ ), the Freedom of the Press Act (Tryckfrihetsförordningen, TF), and the Fundamental Law on Freedom of Expression (Yttrandefrihetsgrundlagen, YGL). The Library Act's emphasis on 'freedom of opinion' is defined as the 'positive freedoms of opinion', encompassing freedom of expression, freedom of information, freedom of assembly, freedom to demonstrate, freedom of association, and freedom of worship, listed in RF Ch 2 Art 1(1-6) 'Fundamental rights and freedoms. ${ }^{15}$ The constitutional laws are superordinate to other laws. 


\section{The right to refuse}

Case 1, from 1996, concerns whether a public library has the right to refuse to lend an individual certain books because of the reason for wanting to borrow them. The case was taken to the Parliamentary Ombudsmen (JO). One of JO's main tasks, under Article 3 of the 1986 Act with Instructions for the Parliamentary Ombudsmen, is to ensure that courts and administrative agencies comply with the constitutional requirements of objectivity and impartiality, and that the fundamental rights and liberties of citizens are not encroached on by the state. ${ }^{16}$ In this particular instance, the complaint to JO pertained to a formal request by an individual, $\mathrm{V}$, who questioned the lending policy of Västerås public library. V had requested an interlibrary loan of two of Martin Luther's anti-Semitic works, Vom Schem Hamphoras und vom Geschlecht Christi (Of the Unknowable Name and the Generations of Christ) and Von den letzten Worten Davids (On the Last Words of David), both first published in 1543. When applying for the interlibrary loan, $\mathrm{V}$ felt the librarian took a 'negative and adverse stance' to his request. V was told that antiSemitic works such as the books in question could not be borrowed, whereupon $\mathrm{V}$ requested the explanation for this decision in writing, referring to the fact that he had had similar requests granted by the same library on previous occasions, resulting in at least one scholarly publication written by $\mathrm{V} \cdot{ }^{17} \mathrm{~A}$ few days later, $\mathrm{V}$ received a letter signed by the head librarian as well as the librarian in question. The letter said that V in fact could borrow the publications requested, since he was able to document the scholarly purpose of his request. The letter also said that the initial refusal on the library's part 'might seem incompatible with freedom of expression and the public library system's free distribution of media, but limitations are sometimes necessary in order to prevent abuse of said freedoms'.

At the time of the complaint the 1996 Library Act had not yet come into force, and no other legislation directly governed the activities of public libraries. However, even since the Act came into force (and this is also the case with the revised Act of 2013), 
there is nothing in it that regulates in detail the activities of public libraries. Furthermore, neither Act obliges a public library to provide written works of a specific nature or to arrange interlibrary loans.

In what follows, I trace JO's line of reasoning in his official decision, with particular regard to the legal arguments, since they have direct bearing on the other cases discussed in this study. JO begins his decision by referring to the previously mentioned RF Ch 2 pertaining to the fundamental rights and liberties of citizens. He stresses that the tenor of $R F \mathrm{Ch} 2 \mathrm{Art} 1$ is 'that the state is to guarantee each citizen freedom of information, described here as the freedom to obtain and receive information and otherwise acquaint oneself with the utterances of others. ${ }^{18}$ On the other hand, JO concludes, this does not imply any obligation on the state to provide information. This means that the provisions for freedom of information do not support the conclusion that a public library is obliged to make all of its books available to the public. JO also refers to the regulations under TF Ch 2 concerning the right of every citizen to access public documents, and he concludes that printed works or similar records that are part of a library's collection cannot be regarded public documents. ${ }^{19}$ This means that there is in fact no constitutional support for an individual claim for access to any item whatsoever in the collection of a public library.

The legal grounds for JO's criticism of the library, however, were mainly the so-called 'principle of objectivity' in RF Ch 1 Art 9: 'Courts of law, administrative authorities and others performing public administration functions shall pay regard in their work to the equality of all before the law and shall observe objectivity and impartiality.' The importance of the principle of objectivity in this case derives from the fact that it becomes operational when the principle of nulla poena sine lege (no penalty without a law) is not applicable.

Hirschfeldt has commented on the principle of objectivity, describing it as a general principle of public law that dictates that public authorities, such as a library (including its staff) should not be affected by other interests than those pertaining to the public 
authority's own mandate, nor should they take extraneous circumstances into consideration when pursuing their duties. ${ }^{20}$ Not only should public authorities observe objectivity and impartiality in their work, they should also act in a manner that does not suggest that they are subjective or partial. Hirschfeldt explains that the requirement of objectivity applies to both the decision-making and the content of the actions by the authority. In turn, the requirement of impartiality applies to how the decision-making process and the actions of the authority are perceived by the individual in question as well as by the public. ${ }^{21}$

The letter signed by the head librarian contained an admission that the staff had asked $\mathrm{V}$ what his purpose was for his loan request. The stated reason for this enquiry was that library staff were 'vigilant where anti-Semitic works are concerned'. JO concludes his decision that:

In my opinion, the principles of objectivity and impartial treatment apply in situations where a public library is dealing with a request from an individual to be allowed access to a printed work that forms part of the library's collection or for an interlibrary loan. In this context, it would be acceptable to establish a principle denying children or young people access to some types of works. Similarly, it would be acceptable for a library to restrict public access to some books in its collection, or to refuse to arrange interlibrary loans, or to arrange such loans only for those involved in research. In the same way it is, of course, totally acceptable for a library not to buy works of a certain type. On the other hand, I cannot find it acceptable to differentiate between adult borrowers so that available works are only provided to those who can show that they have the 'correct' opinions or that they are well-enough informed about certain subjects. Nor do I consider it acceptable to base the decision whether or not to arrange an interlibrary loan on such differentiation. ${ }^{22}$ 
JO finds it was an aggravating circumstance that the library enquired as to the purpose of the loan request, and only acceded to the request (from, as it turned out, the library's own collection) after a 'serious purpose' could be ascertained. By trying to establish the nature of V's purpose and referring to that as grounds for approving the loan, the library had in fact admitted that V's political and religious standpoints were taken into account in their decision-making. Analogously, had V expressed a point of view considered by the staff to be unsuitable, his request would not have been granted. JO finds, in light of the application of the principle of objectivity, that it is unacceptable to differentiate in this way between individuals applying to borrow library books.

\section{Values and opinions}

The two more recent cases, both from 2016, are here described back-to-back since they are very similar. In fact, so similar that JO summarizes both cases separately but with identical headings: 'With the exception of criminal statements, a public library is not allowed to take into account values and opinions expressed in a printed work when the library decides whether to accede or not to accede to a request for an acquisition or an interlibrary loan.23

In Case 2, $\mathrm{H}$ complained of the handling by the Botkyrka Culture Council (the municipality of Botkyrka being part of the greater Stockholm area) of his request to borrow two works of (purported) non-fiction. The works in question were Invandring och mörkläggning: En saklig rapport från en förryckt tid ('Immigration and cover-up: An objective report from an age of insanity') and Muhammeds flickor: Våld, mord och våldtäkter i Islams hus ('Mohammad's Girls: Violence, murder and rape in the House of Islam'). ${ }^{24}$ In his complaint, $\mathrm{H}$ questioned whether the handling met $R F^{\circ}$ s requirements. The other, similar case, Case 3, involves a complaint made by $\mathrm{T}$, criticizing the Falköping Culture Council for its handling of his request to borrow the (purported) non-fiction book Världsmästarna: När Sverige blev mångkulturellt ('World champions: When Sweden 
became multicultural'). ${ }^{25}$ In his complaint, T said that both the library and the Culture Council had failed to comply with the $R F$ s requirements regarding objectivity and impartiality. T also commented on the disparity that the book was available in many other public libraries in Sweden.

The reason for the two complaints was in both cases that the libraries in question refused to comply with the borrowers' requests. When prompted by JO to explain their handling of the cases, in particular in the light of RF Ch 1 Art 9 and the Library Act Art 2 \& 6, their responses were similar. As regards Case 2, Botkyrka Culture Council responded with a twofold reason: it found that the requirement of 'quality' expressed in Library Act Art 6 justifies an active selection regarding acquisitions, deselections, and interlibrary loans, as well as other library services. The Culture Council justified this selection on grounds of quality by referring to JO's decision from 1996 (on Case 1 in the present study); with regards to the particularities of the case, it stated that the works in question failed to meet the quality demanded by the library, and that this assessment could be shown to have been made in a professional manner. ${ }^{26}$ However, the Culture Council recognized, and indeed regretted, the lack of clearly formulated guidelines and quality criteria, as well as the written reasons for the library's decision, originally addressed to $\mathrm{H}$, which listed the various reasons why the works were found to be lacking in quality. Among other things, the written reasons said that the works in question failed to comply with the city of Botkyrka's general 'Intercultural Action Plan. ${ }^{27}$ The Culture Council, in its statement to JO, acknowledged that these particular grounds were 'sub-optimal', possibly amounting to a violation of the principle of objectivity, particularly since the library's letter did not explain how the works in question violated the Intercultural Action Plan. ${ }^{28}$ The Culture Council's conclusion was that the library had broadly speaking proceeded in accordance with the law, particularly as regards the requirement for quality under the Library Act Art 6. The Council acknowledged, nonetheless, the need for better, more transparent guidelines and routines regarding 'quality' as a screening tool. ${ }^{29}$ 
In a similar vein, Falköping library in Case 3 gave as its stated reasons to JO that back in 2011, at the time of its original publication, the library had decided not to acquire the work in question, because it was found 'lacking in quality' - according to the quality criteria expressed in Falköping library's 'Media Plan'. ${ }^{30}$ When T asked the library to acquire or arrange an interlibrary loan of the work in 2016, the library's original decision was formally reconsidered, but the conclusion was ultimately, yet again, that the work did not meet the quality criteria set in the Media Plan. The Media Plan in fact explicitly states that the library reserves the right to decline requests for acquisitions and interlibrary loans for printed works that do not meet the quality criteria. ${ }^{31}$

JO's decisions in both these cases were in most respects identical. The decisions were also somewhat more detailed than for Case 1 in 1996, with a summary of the general legal principles pertaining to the cases, as well as of the principle of objectivity and a description of the Library Act. Suffice to say, in both Cases 2 and 3 the grounds for JO's criticism was based not on the application of 'quality' per se under the Library Act, unless, as JO put it, 'quality is used as a pretext to deselect a printed work due to opinions expressed in the work', but on how the libraries and Cultural Councils, by referring respectively to an Intercultural Action Plan and a Media Plan, justified their handling and decision-making regarding the requests. In regards to Cases 2 and 3, I wish to focus on other aspects of JO's stated 'Vantage Points' - which are identical for both cases and contain some interesting and thought-provoking interpretations of the legal principles.

JO begins his decision by stating that a 'public library cannot—and should not-provide all books', and concludes that the Library Act postulates that a selection must in fact take place. ${ }^{32}$ The legislative history of the Library Act furthermore describes a selection based on the democratic function of the public library system, and its objectives to promote knowledge and freedom of opinion by means of a comprehensive and qualitative selection. The legislative history also stresses that public libraries must remain neutral vis-à-vis 
the information they provide, and that they may not in any way limit their selection criteria on ideological, political, or religious grounds. JO concludes that the principles for selection stated in the Library Act 'are to be regarded as an emanation of the general requirements of public authorities in accordance with the principle of objectivity (1.9 of the Instrument of Government) as well as with the principles of freedom of expression and freedom of information in the Instrument of Government. JO furthermore states that the duties of his (or her) office do not stretch to quality judgements about printed works, nor to opinions on what selection of printed works a single library ought or ought not to provide, 'unless', as JO puts it, 'special requirements should warrant such an action.' ${ }^{33}$

Interestingly, JO's legal opinion contains a literary distinction of sorts. When reminding the reader of the public library system's fundamental function to promote knowledge, JO concludes that the operationalization of this function will need to differ 'depending on the kind of literature in question'. JO continues:

It seems natural that the demands on literary fiction should differ from the demands on other kinds of literature. When it comes to other forms of literature than literary fiction, the scrutiny conducted by the libraries regarding the reliability of a printed work constitutes an important aspect of the fulfilment of their obligation to promote knowledge. In my opinion, it is obvious that the public libraries' task to promote freedom of opinion does not oblige them to remain neutral to deficiencies in scholarly quality or outright errors in a non-fiction work. ${ }^{34}$

In addition, JO's legal opinion constitutes a form of epistemological disquisition when he concludes that in the case of polemics 'and books of that ilk', it is in many instances hard to ascertain whether a statement constitutes a factual statement, which in itself can be either correct or false, or if it constitutes an opinion. According to JO, this difficulty increases when the author 'weaves facts and opinions together'. JO comes to the, perhaps questionable, conclusion 
that it should be possible for libraries to gauge the factual qualities of a text, regardless of whether the text in fact promotes the opinions of the author. By way of clarification, JO states that 'a printed work may contain utterances and expressions that are criminal (for example hate speech, slander, or incitement)', and though such utterances can be expressed as opinions, JO states that 'To abstain from acquiring a printed work because it contains criminal utterances is not in conflict with the principle of objectivity, even if it is expressed as an opinion. ${ }^{35}$

\section{Truth, power, and socially structured silences}

JO's decisions, particularly concerning Case 3, the Falköping case, contain some interesting deliberations on the distinction between fiction and non-fiction, as well as on factual statement versus personal opinion.

The express purpose of Falköping's Media Plan was to enable the library to work more strategically and methodically with acquisitions, weeding its collections, and an active, curated showcasing of select contents of the library (e.g. by means of presenting thematic selections or active presentations of works correlating to current affairs). When it comes to what literature the library should provide, the Media Plan states under the heading 'Quality' that the library should provide a selection of both popular, much-requested literature and more select, less-sought-after literature. When it comes to acquisitions, the Media Plan explains that quality can be assessed in three different ways, with a brief explanation of each criteria: literary quality is about character portrayal, narration, and language; value, gender roles, xenophobia, racism, and similar matters; and trustworthiness, reliability and timeliness. ${ }^{36}$ The Media Plan furthermore establishes a hierarchy by stating that 'we consider values to be the most important', and it concludes that a public library cannot make media available 'that glorify or propagate violence, racism, sexism, or other things that go against the Universal Declaration of Human Rights. This principle seems to apply equally to fiction 
as to non-fiction. Under the same heading, the Media Plan also states that the quality criteria may be used to justify the library's rejection of suggested acquisitions if the works in question do not meet the demands of the criteria. Again, later in the document under the heading 'Interlibrary Loans', the Media Plan states that requests for interlibrary loans will not be honoured for books that fail to meet the quality criteria.

In the local authority's reply to JO's inquiry about the Falköping case, it stated that for lack of time and resources, the assessment of literature is generally not conducted at the library, but by subscribing to the services of BTJ (formerly Bibliotekstjänst), a company that specializes in delivering media and information services to professional customers, mainly libraries and universities. ${ }^{37}$ It should be noted that most, if not all, Swedish public libraries use BTJ's services and rely heavily on their reviews when making acquisitions. The written assessments or reviews (120 to 150 words long) published by BTJ are written by commissioned, professional readers, thus guaranteeing — so Falköping argued — a certain level of objectivity and impartiality.

That said, BTJ's instructions for its readers are fairly generic. There are separate checklists for fiction and non-fiction, as well as for children's and young adult literature and other media forms. The instructions contain general information as well as a thirteen-point checklist for what a non-fiction review should address. Apart from basic information such as a brief author presentation, a precis, and a description of 'style and language', the memo also asks the reader to provide an 'account of the thrust of the book in respect to politics, ethics and similar matters. ${ }^{38}$ The rubric states that reviews must be objective and impartial, and explicitly states that 'the opinions expressed in the book/media should not be reviewed, but should always be described.. ${ }^{39}$ Also, when it comes to works of non-fiction, the reader is asked to give an assessment of the 'professional reliability of the work'.

All three cases included works of purported non-fiction, and what was at stake can be found at the intersection of the quality 
criterion expressed in the Library Act, JO's differentiation between factual statement and personal opinion, the categories of 'Value' and 'Trustworthiness' found in the Falköping Media Plan, and the assessment of 'professional reliability' as required by BTJ. It is not too much of a stretch to conclude that the heart of the matter is 'knowledge', or perhaps even 'truth'. This is in fact no coincidence. 'Truth', defined as a function of facts and fact-based analysis, is one of the primary battlefields of the twenty-first century, where trust and reliance on facts and analytical interpretations of facts and data versus opinions and personal attitudes seem to have shifted in favour of the latter in contemporary public discourse. The research report Truth Decay (2018) addresses these issues by identifying the four trends driving 'truth decay':

an increasing disagreement about facts and analytical interpretations of facts and data; a blurring of the line between opinion and fact; an increase in the relative volume, and resulting influence, of opinion and personal experience over fact; and declining trust in formerly respected sources of factual information. ${ }^{40}$

Whereas I have deliberately adopted a neutral stance vis-à-vis the works in the three cases outlined above, it is sufficient to say that the cases exemplify these trends. Instead of regarding the division between 'truth' and 'opinion' as absolute, I deem it necessary to regard it as a non-trivial continuum-illustrating to some extent Sue Curry Jansen's concept of 'socially structured silences', where the concept of truth and knowledge is intertwined with power. ${ }^{41}$ As Jansen stated in her seminal study of censorship, 'knowledge and power are still bound together in an inextricable knot. ${ }^{42}$ She recognizes that knowledge in its modern understanding is not simply conceived of as an instrument of power, but rather that power secures knowledge, while at the same time it is equally true that knowledge secures power. It is precisely this 'knot', irrespective of the factual content of the three works in question, that the cases of this study illustrate. 
What comes to light in this three-part case study is a paradox of sorts. The 'enlightened', liberal state that upholds the key principle of freedom of speech must also somehow retain the capacity to uphold its stability by being able to respond to the conceivable threats that this same freedom generates, in order to preserve its status as a liberal society. Innate in every modern democracy, until now at least, are the means to exercise a form of intellectual domination that is 'constitutive' in nature-in other words, it is manifested in invisible (or hegemonic) restrictions, since they arise spontaneously out of ordinary social forces. And whereas 'truth' is an area of contention in modern liberal democracies, it is questionable whether it can be resolved while maintaining the 'operationally effective fiction' of liberal democracies, to use Habermas's term, of an unrestricted freedom of speech. ${ }^{43}$

\section{Notes}

1 Karolides 2006, 12; the other books in the Banned Book series are Bald 2006 and Sova $2006 \mathrm{a}-\mathrm{b}$.

2 See Savolainen in this volume for an investigation of the restricted access of children to the collections of public libraries in Finland.

3 See the introduction to this volume; see also Johansson in this volume for a historical example of conservative struggle against perceived decadent literature in Sweden.

4 This study was part of the project 'The Welfare Regime of Literature: The Function of Literature in Sweden 1937-1976', funded by the Swedish Research Council, 2019-2021 (ref. 2018-01078).

5 Rosenfeld 2001, 140.

6 SOU 2016:5 Låt fler forma framtiden!, 75.

7 See also Erlanson and Henning's contribution in this volume.

8 Fichtelius et al. 2017, 465-75. Unless otherwise stated, all translations are my own.

9 Fichtelius et al. 2017, 465 .

10 Frenander 2012, 74.

11 SFS 2013:801 Bibliotekslag.

12 Hirschfeldt 2017, 70.

13 Ibid. 73 .

14 Ibid. passim. 
15 SFS 1974:152 Regeringsformen $(R F)$.

16 SFS 1986:765 Instruktion: Lag (1986:765) med instruktion för Riksdagens ombudsman.

17 Dnr 3622-1996, Justitieombudsmännens ämbetsberättelse 1998-99 (1998/99:JO1), 534: 'Fråga om ett folkbibliotek ägt vägra låna ut vissa böcker till en person med hänsyn till dennas syfte med lånet.'

18 Justitieombudsmännens ämbetsberättelse 1998-99 (1998/99:JO1), appendix 5, 641, in the official English translation of the summary of JO's criticism: 'Whether a public library had the right to refuse to lend an individual certain books because of his reason for wanting to borrow them'.

19 SFS 1949:105 Tryckfrihetsförordning (TF) Ch 2. Art 11.3.1.

20 Hirschfeldt 2017, 75.

21 Ibid. 75 .

22 Justitieombudsmännens ämbetsberättelse 1998-99 (1998/99:JO1), appendix 5, 641-2: 'Whether a public library had the right to refuse to lend an individual certain books because of his reason for wanting to borrow them.'

23 Justitieombudsmännens ämbetsberättelse 2017-18 (2017/18:JO1), 560, 569: 'Med undantag för brottsliga yttranden får ett folkbibliotek inte ta hänsyn till de värderingar och åsikter som förs fram i en bok när biblioteket tar ställning till om boken ska köpas in eller fjärrlånas.'

24 Karl-Olov Arnstberg \& Gunnar Sandelin (2013), Invandring och mörkläggning: En saklig rapport från en förryckt tid (Skärholmen: Debattförlaget); Lars Hedegaard (2014), Muhammeds flickor: Våld, mord och våldtäkter i Islams hus, tr. Maria Celander (Fredriksberg: Free Speech Library/Trykkefrihedsselskabets bibliotek).

25 Julia Caesar (pseudonym) (2010), Världsmästarna: När Sverige blev mångkulturellt (Visby: Nomen).

26 Dnr 2654-2016, Justitieombudsmännens ämbetsberättelse 2017-18 (2017/18:JO1), 563 .

27 Ibid. 562.

28 Ibid. 563 .

29 Ibid. 564.

30 Dnr 4650-2016, Justitieombudsmännens ämbetsberättelse 2017-18 (2017/18:JO1), 572.

31 Falköpings bibliotek 2004.

32 Dnr 4650-2016, Justitieombudsmännens ämbetsberättelse 2017-18 (2017/18:JO1), $574 \mathrm{ff}$.

33 Ibid. 575 .

34 Ibid. 575 .

35 Ibid. 576.

36 Falköpings bibliotek 2004.

37 Formerly Bibliotekstjänst (Library Services), BTJ was founded on the initiative of the Association of Swedish Public Libraries (SAB), and became a limited 
company in 1960. With the assistance of a large number of lecturers, BTJ is able to provide (brief) reviews of many, but not all, publications in Sweden; however, the number of BTJ reviews far exceeds the number of publications reviewed in daily newspapers and other media.

38 Personal communication, 'Lektörs-PM, Bibliotekstjänst' [internal memo].

39 Ibid.

40 Kavanagh \& Rich 2018, x-xi, also https://www.rand.org/pubs/research_reports/ RR2314.html, accessed 31 Oct. 2019. The RAND Corporation (the name stands for 'Research ANd Development') is an American non-profit organization that promotes a wide variety of scientific and educational projects, for example the world's largest $\mathrm{PhD}$ programme on policy analysis. Among its clients and funders are several US government agencies and US universities, as well as several EU agencies and international organizations such as the OECD and WHO. For further funders, see https://www.rand.org/about/clients_grantors. html\#international-organizations, accessed 30 October 2019.

41 Jansen 1991, 9.

42 Ibid. 4.

43 The term used by Habermas 1973, 258-'operationally effective fiction'-has been used in various contexts. Originally, it referred to a form of ideal, which despite being fictitious nonetheless determined people's patterns of thought or their approach to certain phenomena; see also the introduction to this volume. 